\title{
研究者識別子ORCIDの取り組み
}

\section{An introduction to ORCID (Open Researcher and Contributor ID)}

\author{
蔵川圭 ${ }^{1}$ 武田 英明 ${ }^{1}$
}

\section{KURAKAWA Kei ${ }^{1}$; TAKEDA Hideaki ${ }^{1}$}

1 国立情報学研究所（干101-8430 東京都千代田区一ツ橋2-1-2） E-mail : kurakawa@nii.ac.jp; takeda@nii.ac.jp

1 National Institute of Informatics (2-1-2 Hitotsubashi Chiyoda-ku, Tokyo 101-8430)

原稿受理 (2011-11-21)

情報管理５4(10), 622-631, doi: 10.1241/johokanri.54.622 (http://dx.doi.org/10.1241/johokanri.54.622)

著者抄録

本稿では 2009 年より始まった国際的な研究者識別子付与活動である ORCID (Open Researcher and Contributor ID) について解説する。ORCID は世界中の研究者に一意の識別子を与えることで，さまざまな学術コミュニケーションを 円滑にすることを目的としている。このために学術コミュニケーションに関与する出版社，大学，研究助成機関等が 集まって非営利法人 ORCID Inc. を設立して，活動の母体としている。現在 300 近い組織が参加している。ORCID のID は個別の研究者にとっては自己の研究業績の集約や他の研究者の業績の発見に役立つ。大学にとっては組織の業績を まとめるのに貢献する。出版社には著者や査読者の同定に貢献する。研究助成機関にとっては, 応募者の同定に役立つ。 ORCID のサービスは 2012 年の初頭に最初の機能限定版が公開され，2012 年中にはより多くの機能を含んだサービス が公開される予定である。

キーワード

研究者識別子，研究者ID，名寄せ，研究者プロフィル，書誌，ORCID，学術情報流通

1.はじめに

ORCID (Open Researcher and Contributor ID) は, 学術情報流通の世界を対象としてさまざまな利害関 係者が集まって研究者の名寄せの問題に取り組む国 際的な組織である。本稿ではORCIDができた背景で ある研究者／著者の識別子と名寄せの問題の現状か らORCIDの活動の紹介，今後の展望を述べる。
2. 研究者識別子とは

まず研究者識別子とはどのようなものであるかに ついて概観する。

2.1 なぜ今研究者識別子なのか

Web以前においては，主な研究情報入手手段は ジャーナルであり，研究者はジャーナル論文の著者 名を頼りに関係論文を探したり，時には著者に直接 連絡をとって論文を手に入れたりしていた。 
ご存じのようにWebはまずは研究情報の共有のた めに開発されたものであり，研究者はWebの最初の ユーザーであった。研究者はさまざまな研究情報を Webを通じて公開したが，その中に自分自身の情報 も含まれていた。自分の名前と関連情報を“ホーム ページ"として公開した。

Webが普及するにつれ，研究情報は大量にWeb上 にあがるようになった。個人のホームページから， ジャーナル論文情報，会議の情報，大学のページ， プロジェクトのページ，等々と多様な情報が公開さ れ，その中に研究者名が含まれている。研究者名が Web上に溢れるようになった。

一方でインターネット／Webは研究のグローバル 化と学際化を加速した。異なる組織・地域の研究者 が容易に共同研究をすることができ，また違う分野 の研究情報が即座に探せるようになり従来の分野に 限られない研究も可能になった。すなわち知りたい 研究者の範囲は格段に拡大した。

このような研究者に関する情報の増大と研究者の ボーダレス化によって，名前に頼った情報の探索が 困難になってきた。

典型的な問題は以下のようなものである。

（1）同姓同名問題：Web検索や論文データベース 検索において同姓同名を区別したい。分野を限らず 検索できるようになったため，ますます同姓同名は 頭の痛い問題となっている。

(2) 異動する研究者の同定：組織を異動した研究 者の情報を把握したい。情報が複数組織の情報源に 分散したり，文献でも異なる所属機関となっている ため同一人物か把握しづらい。

(3) 研究者IDの統合：近年，多くのサービスが名 寄せのために著者や研究者のIDを提供している。一 人の研究者がそれぞれのサービスで別のIDになって いる。このようなIDを研究者ごとにまとめたい。

（4）所属研究者の情報の集約：大学などの組織が 自組織所属の研究者の活動を集約したい。すべての 研究情報に所属組織が書かれているわけではないの
で，組織名だけでは調べることができない。

そこで世界中のすべての分野の研究者を一意に同 定する識別子が求められるようになった。

\section{2 研究活動の異なる立場}

研究者を識別する識別子は個別の人にIDをつ けていくという処理であり，DOI (Digital Object Identifier，デジタルオブジェクト識別子）や類似の方 法で簡単にできると思われるかもしれない。しかし， 研究活動というのは多様な関係の中で行われており， その結果，研究者識別子付与はDOはととと同様には行 うことが難しい。

さまざまな社会活動の中で，芸術活動，芸能活動， 政治活動などと並んで，研究活動は個人の名前が重 要な分野の1つである。研究者は自分の名前で研究を 行い，研究成果を公開する。この点では研究は個人 的活動である。前述のようにWebで先頭をきって個 人の活動を公開してきたのもそれ故である。

一方で研究活動は単に個人的活動ではない。列挙 した他の活動は組織とは無関係あるいは一線を画し た活動なのに比べ，研究活動は大学などの所属組織 の活動と密に関係している。多くの研究は組織の中 の活動であり，また研究者の大学への帰属意識は概 ね高い。

さらに研究活動は出版活動でもある。成果は研究 論文として発表され，多くは出版物として流通して いる。個々の出版社は出版物の著者として研究者の 情報を収集している。また各国の中央図書館はやは り著者としての研究者の情報を収集している。

さらに研究活動は公的活動でもある。研究そのも のが公共の知に貢献するという概念的な意味でも公 的であるし，政府等の資金を直接的・間接的に利用 している実際的な意味でも公的である。このため， 資金助成機関も研究者の情報を保持している。

これらの側面の関係は簡単ではない。個人的活動 と組織的活動は時には対立する見方であり，当事者 か否かという点においては個人・組織と出版・公的 
機関は異なる立場となる。

\section{3 研究者識別子の特徵}

研究活動はこのように異なる側面を持ち，この特 徵が研究者のアイデンティティも形作っている。重 要でかつ問題を複雑にしているのは，1つの側面か らだけではうまくいかないという点である。研究者 の識別子は，個々人が取得する識別子であり，組織 が与える識別子でもあり，出版社が与える識別子で もあり，公的機関が与える識別子でもあるような性 質を持たないといけない。そして，研究者識別子は， 個人のプロファイル，組織内の活動，研究業績（発 表文献），助成を受けたプロジェクトなど，それぞれ の視点から多様な情報と紐づけられる。

\section{ORCIDの経緯と組織}

ORCIDは，上記のような多様な利害関係者が集まっ て，研究者識別子に取り組む国際的な組織である。

\section{1 経緯}

2009年11月9日，米国ボストンで研究者の識別子に 関心のあるいくつかの主要な利害関係者が集まって， 名前識別子サミット (The Name Identifier Summit) が開かれた1)。チェアは,トムソン・ロイターのコチャ ルコ（David Kochalko）とネイチャー出版グループの ラトナー (Howard Ratner) であった。これがORCID 発足のための最初の会議となった。この会議を受け て2009年12月1日，ORCIDと名づけられる統一的な研 究者IDを作るという宣言がなされた。その後，ORCID Initiativeとしてアメリカ東海岸とロンドンで数度会合 を持った。

その上で，2010年8月に米国デラウェア州の非営利 法人ORCID, Inc.として発足した。米国における内国歳 入法典第501条C項3号の規定に基づく非課税非営利法 人に申請予定である。発足については，2010年9月7 日にプレスリリースを出している2）。の時点で115
の参加組織があった。

\section{2 組織}

ORCID, Inc.（以下ORCID）は，14人の理事からなる 理事会により運営される。定款に理事の過半数は非 営利の組織からなると規定されている。現在の理事 は表1の通りである。

大学，研究所，学会，非営利法人，基金の非営利 の組織から10名，出版社と企業から4名である。研究 活動との関係で分類すれば，研究者の所属組織（大 学)，出版や出版情報に関わる組織（出版社，学会な ど)，出版以外の研究者情報に関わる組織（基金，助 成機関など）に分かれている。

理事の中から互選で代表を含む執行委員会が選任 されている。ネイチャー出版グループのラトナーが 理事会代表，トムソン・ロイターのコチャルコが会計， ハーバード大学のブランド (Amy Brand) が書記に 選出された。この3人に加えてウェルカム財団のアレ ン (Liz Allen)， ACMのラウス (Bernard Rous), ワイ リーのバン・ディック (Craig Van Dyck) の3名が執 行委員会を構成する。

理事会の下に現在3つの作業部会 (Working Group) が設けられている。ORCIDの経営方法を検討するビ ジネス作業部会，システムの仕様を検討する技術作 業部会，広報などを行うアウトリーチ作業部会であ る。

\section{表1ＯRCIDの理事会構成}

\begin{tabular}{|l|l|l|l|}
\hline \multicolumn{1}{|c|}{ 理事名 } & \multicolumn{1}{c|}{ 所属組織 } & \multicolumn{1}{c|}{ 組織種別 } & \multicolumn{1}{c|}{ 役職 } \\
\hline Liz Allen & Wellcome Trust & 基金 & 執行委員会 \\
\hline Amy Brand & Harvard University & 大学 & 書記 \\
\hline Craig Van Dyck & John Wiley \& Sons, Inc. & 出版社 & 執行委員会 \\
\hline Martin Fenner & Hannover Medical School & 大学 & \\
\hline Diane Geraci & $\begin{array}{l}\text { Massachusetts Institute of Technology } \\
\text { Libraries }\end{array}$ & 大学 & \\
\hline Thomas Hickey & OCLC & 非営利法人 & \\
\hline David Kochalko & Thomson Reuters & 企業 & 会計 \\
\hline Salvatore Mele & CERN & 研究所 & \\
\hline Ed Pentz & Publishers International Linking & 非営利法人 & \\
\hline Howard Ratner & Association, Inc. (CrossRef運営) & & \\
\hline Bernard Rous & Association for Computing Machinery, Inc. & 出版社 & 代表 \\
\hline Chris Shillum & Elsevier & 執行委員会 \\
\hline Hideaki Takeda & National Institute of Informatics (NII) & 研究所 & \\
\hline Simeon Warner & Cornell University Library (arXiv.org運営) & 大学 & \\
\hline
\end{tabular}




\section{3 設立趣旨}

ORCIDの設立趣旨は公式ホームページ上に掲げら れている3)。

$\Gamma \mathrm{ORCID}$, Inc.の目的は，学術コミュニケーションに おける著者および寄与者の名前同定問題を，個々の 研究者に固有の識別子の与える中央レジストリと， ORCIDと他の著者IDスキーマと関連づけるオープン で透過性のある機構を創設することで解決すること である。科学的発見のプロセスを強化したり助成や 研究コミュニティにおける共同研究の効率性を上げ るために，識別子と相互の関係は研究者の業績にリ ンク可能である」

英語版に加え，スペイン語訳と日本語訳も掲載さ れている。

\section{4 参加組織}

ORCIDへの参加は組織単位となっている。現在の ところは参加は興味の表明の意味であり，参加メン バーに特に権利もないし逆に参加費などの義務もな い。アウトリーチ集会へ参加できることぐらいであ る。
2011年11月17日現在で約280の参加組織がある。 参加組織を種類別にわけると図1の通りである。大学 等のアカデミアが4割，出版社等の企業系が3割，学 会や非営利機関が2割という分布である。学術機関と 出版社が半分を占めている一方，それ以外の多様な 関係者がいることがわかる。また，国別の分布を図2 に示す。米国と英国が圧倒的多数であり，アジアか らの参加は少数である。

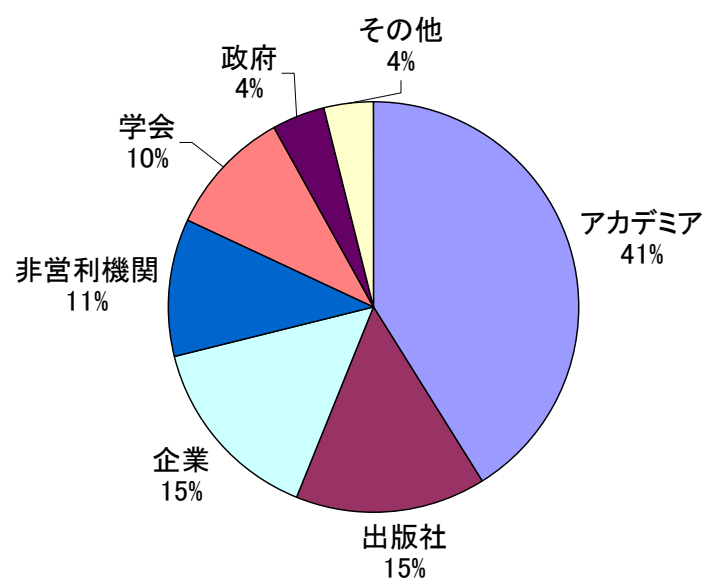

ORCID Webサイトの “Participating Organizations” （http://orcid.org/participants）より作図

図1 参加機関の種類別分布
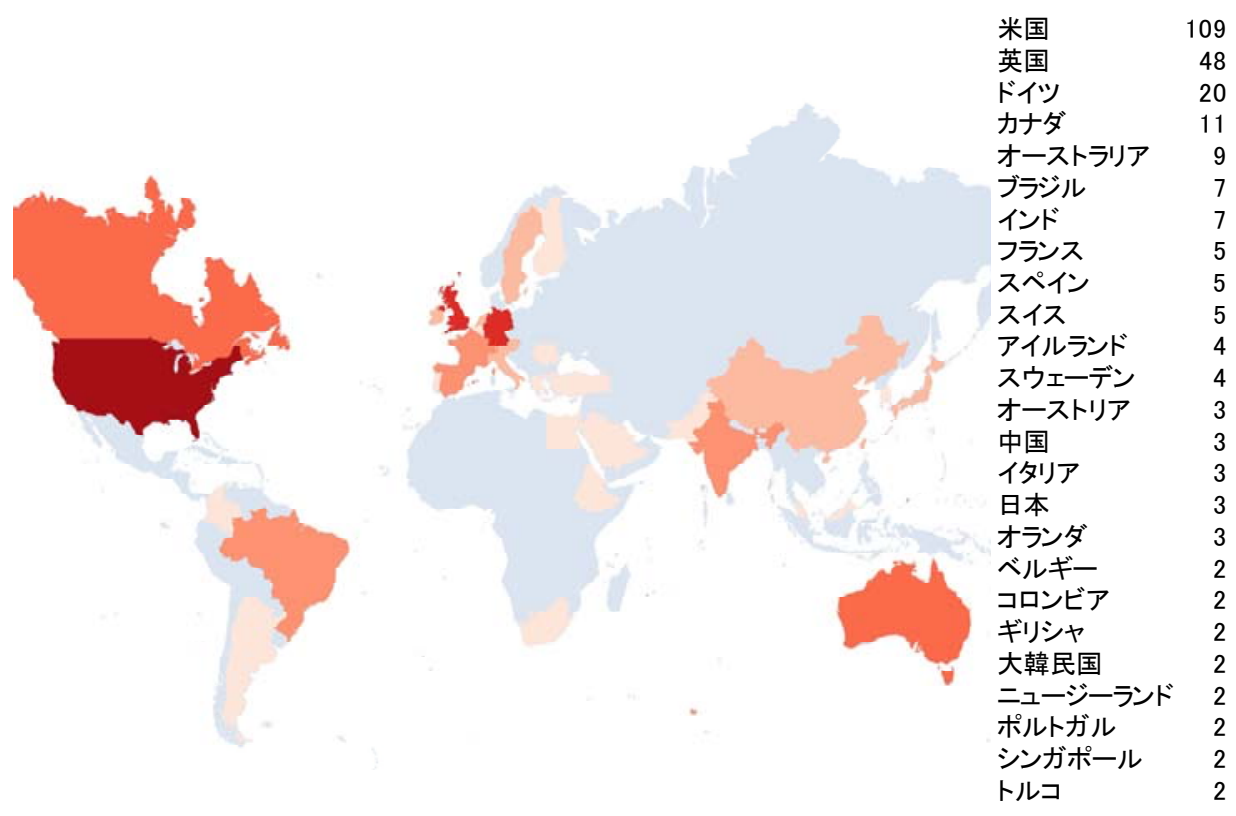

ORCID Webサイトの“Participating Organizations” (http://orcid.org/participants)より作図

図2＼cjkstart参加機関の国別分布（2組織以上参加の国のみ表示） 


\section{ORCIDのポリシーと原則}

ORCIDの運営指針となる原則 (Principles) がビジ ネス作業部会によって議論され，2010年10月に公開， 12月8日に公式ホームページに掲載された4)。原則は 10項目からなっており，これに基づいてビジネスモ デルやシステムの機能が決定される。

原則では，まず，ORCIDが著者と貢献者を確実に 特定できるようにすることによって，学術コミュニ ケーションにおける，固定の，明確な，曖昧でない レコードの作成を支援することを宣言し，学術分野， 地理，国籍，機関の境界を超えた，オープンで透明 性のある組織であることを明示している。

そして，研究者はORCIDのサービスを介して自由 にIDとプロファイルを登録することが可能であり， その際プライバシーには十分に配慮することとして いる。研究者のプロファイルデータは，プライバシー 設定後，クリエイティブコモンズがCCOと定義する権 利放棄5) の形で公開される。研究者のデータに対す る権利について議論を積み重ねた結果，ORCIDから 公開するデータについて権利放棄を明示することに なった経緯は強調しておきたい。

また，ORCIDの開発したソフトウェアはオープン ソースイニシアチブのオープンソース6) として公に リリースすることとした。オープンソースとしての 公開を決めたことは，ボランティアベースによる開 発コミュニティーを構成することでソフトウェア開 発コストを削減したい思いがある。

ORCIDのビジネスモデルは，組織が非営利であり ながらも持続可能であるための必要最低限の収入を 得ることを目的としている。そのためのシステムの APIは有料と無料の双方によって構成されることを明 示している。

最後に，組織内部の構成が非営利であり，活動内 容について最大限に透明性を確保することをうたつ ている。

\section{ORCIDの役割}

前述したようにORCIDには研究者個人，研究機関， 学会，出版社，資金提供機関とさまざまな人・組織 が関与する。ORCIDはこれらのそれぞれに対し異な る役割を持つ。

\section{(1) 研究者}

ORCIDの情報を論文投稿の時や求職の時，研究資 金応募の時に利用する。研究者はピアレビュー，デー タキュレーション, ソフトウェア開発を含むさまざ まな学術的記録をORCIDに置くことができるように なる。ORCIDを通じてこういった情報を公開するこ とで研究者は新たな共同研究者を見つけるといった 研究のネットワーク構築ができるようになる。

\section{（2）大学および研究機関}

ORCIDを自組織メンバーの行う研究の実績の評価 に使うことができる。また採用時の評価にも使うこ とができる。これらの組織はORCIDを使うことで， 組織の強みのある分野の同定や構成員の実績の追跡 をより容易にできるようになる。

\section{(3) 学会}

ORCIDを使って学会員のプロファイル情報を強化 したり，さらには学会員の研究成果の公開や学会員 間のコラボレーション支援に使うことができる。

(4) 出版社

投稿システムにおいて著者や査読者の追跡を確実 にできるようになる。同一著者の論文や共著者を関 連づけて，関連学術成果の発見などに使うことがで きる。

\section{（5）資金助成機関}

申請処理においてORCIDのIDを使うことで申請者 の情報を簡単に入手できるようになり，処理を簡略 化できる。また研究評価の段階においても個々のプ ロジェクトの評価に使うことができる。

さらにORCIDのIDを使うことで，学術コミュニケー ション全体がよりスムーズになることが期待でき る。例えばデータベースやソフトウェアの貢献者の 
同定や学術的なブログやwikiなどにおける著者同定に も利用できる。

\section{ORCIDのサービス}

現在計画されているORCIDサービスは以下のよう なものである。

ORCIDシステムでは各研究者にユニークなID（以下 ORCID ID）を付与する。ORCID IDは研究者個々人の 申請により作られるが，それに資金提供機関，学会， 出版社が一括してアップロードして研究者の基本情 報と結びつけられる。

基本プロファイル情報は名前や所属といった最小 限のものである（まだ議論中）。その上に，研究成果 や獲得資金といった情報が必要に応じて結びつけら れる。

ORCIDシステムは他の研究者ID・著者ID，研究者プ ロファイルシステムと連携して運用することを想定 している。ORCID IDは基本情報を保持し提供するこ とで，出版社の原稿投稿システムや資金提供機関の 申請システム，研究者プロファイルシステムなど多 様なシステムを使う研究者の労力を最小化する。

ORCIDサービスは現在，2段階で計画されている。 フェーズ1は2012年初頭に開始し，フェーズ2は2012 年末を予定している。フェーズ1では現在活動中の 研究者を対象として，研究者個人と研究機関（大学） からの情報入力を受け付ける。またトムソン・ロイ ターのResearcherIDシステムに基づき，プライバシー 制御やCrossRefとの連携などを実装する予定である。

フェーズ2では研究活動を過去の研究者も対象とし て，出版社や学会・資金提供機関なども利用できる ようにする。このために複数の記録にある名前が関 連づけられるように名前同定の問題解決を行う。

\section{ORCIDシステムの詳細}

ORCIDのコアシステムとなるIDシステムに関する
議論は，2010年2月から9月ごろまでの間，技術作業 部会によって行われた。どのようなシステムである べきか，システムの要件が議論され，アルファ版の プロトタイプが構築された注1)。その後，続けてプロ ダクションシステムとしてのベータシステムの構築 に向けて議論が進んでいる。

\section{1 基本的な考え方}

IDシステムにおいて，アイデンティティとして扱 う基本的な情報は，

・著者／貢献者自身の記述

・著者／貢献者とその出版物間の関係の記述 の2種類である。「著者／貢献者自身の記述」は名前 や所属などを含み，研究者のプロファイルである。 「著者／貢献者とその出版物間の関係の記述」とは， 研究の業績とする論文や記事，書籍，データなどを 含むリストであり，出版物申告 (Publication Claims) と呼ぶ。これらがORCIDIDと紐づけられることにな る。

プロファイルと出版物申告の登録は，著者／貢献 者と組織の双方が行うハイブリッド型による方式が 提案されている。著者／貢献者自身によるだけでは 情報が集まりにくいので，組織がまとめて情報を登 録することによって呼び水とするわけである。

システム要件の議論は，CrossRefがこれまで Contributor IDとして議論してきた内容を拡張してい る。ここでは，エンドユーザー，パートナーシステ ム、コアシステムの3つの主体が登場する（図3）。

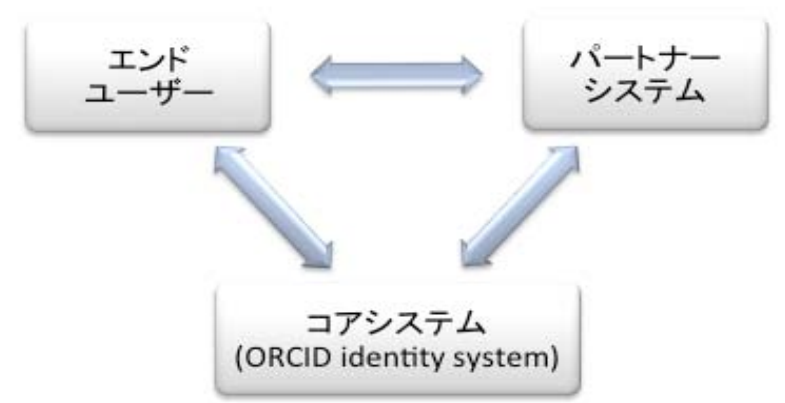

図3 システム要件における3つの主体 
エンドユーザーは，著者，貢献者，部門管理者，そ の他のさまざまな人である。パートナーシステムは， 出版者の原稿追跡システム（Manuscript Tracking System）や研究者ディレクトリ，論文検索システ ムなど関連するシステムである。コアシステムは， ORCIDのIDシステムそのものである。エンドユーザー は，コアシステムに対して，プロファイルや出版物 申告を登録して作成し，編集，更新する。大学や研 究機関，出版者などの組織は，パートナーシステム からコアシステムに対し，プロファイルや出版物申 告をまとめて登録する。コアシステムでは，複数の プロファイルを集めて，マッチングや重複解消をし て著者／貢献者の主プロファイルを自動で作成した り，著者／貢献者自らが手動で名寄せするのを支援 したりする。そのほか，システムと人，システム間 のやり取りを示す個々のユースケースが技術作業部 会で議論され想定される技術が列挙された。

\section{2 パートナーシステムとの連携}

ORCIDのシステムは，さまざまなパートナーシス テムと連携する。連携の在り方はさまざまなシナリ オとして考えられているが，最も重要なものはパー トナーシステムとORCIDのシステムがプロファイル 交換を行うことである。研究者のIDやプロファイル を独自に保持して，すでに利用されている，例えば 次のようなシステムと連携する。トムソン・ロイター のResearcherID，エルゼビアのScopus，国立衛生研 究所 $(N I H)$ の助成を受けて開発し全米で利用され

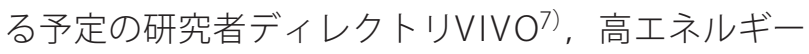
分野の論文を対象とした論文検索システムINSPIRE ${ }^{8)}$ ， 経済学分野の論文を対象とした論文検索システム RePE ( ${ }^{9)}$ ，ProQuest社の研究者ディレクトリAuthor Resolver ${ }^{10)}$ ，NIHの運営する医学生物系論文検索シス テムPubMed ${ }^{11)}$ である。このようにすでに権威があ り，利用頻度が高くユーザー数の多い既存のシステ ムと連携することは，より信頼性高くすべての研究 者を網羅することを可能とする。

\subsection{ID システムのデータモデル詳細化}

フェーズ1に予定されているベータシステムは，現 在活動中の研究者を対象とし，研究者と団体の双方 がアイデンティティを申告することを想定してい る。データは個人と組織の双方から登録されるため， ある研究者に対してレコードは重複し，識別子，レ コード，研究者にn-n-1の対応をつけなければならな い。n-n-1の対応というのは，個人の登録も含めてさ まざまな組織からある研究者のレコードが登録され る状況では，同一研究者に対する識別子が複数付与 され，同様にレコードも複数登録されるため，最終 的にはそれらがある一人の研究者に紐づけられる必 要があるということを意味している。ORCIDが重複 するレコードを受け入れることを容認したのは，登 録数がクリティカルマスに早期に到達すること，あ まりアクティブでない研究者のデータの提供につい て第三者団体からの申告を見込んでいるからである。

技術作業部会のサブグループの1つでは，同一人 物のレコードを判定するアルゴリズムについて議論 したが，十分な結果は得られなかったため，アルゴ リズムと手動による名寄せのハイブリッドシステム が必要だということになった。その上で，レコード のコントロールとオーソリティについて解決してい く。つまり，信用すべきデータの決定方法，同一研 究者を指す複数のデータの処理方法，識別子やレコー ドの管理修正の権限の方法についてである。

フェーズ1におけるベータシステムの開発はビル ダー (Geoffrey Bilder) が主導しており，研究者や 第三者団体がどのように申告するかというシナリオ を考慮しつつ，上述の問題に対処する方法が提案さ れている12)。ここではさまざまな団体から申告され るレコードを重複解消して消去するのではなく，研 究者本人の申告レコードとそれぞれの団体の申告レ コードが “同じである”と宣言して関係を表明する。 あるレコードとあるレコードが “同じである”と関係 を表明した後、レコードに記述される所属や職名な どの個々の属性に関しては妥当かどうか検証すると 
いう形をとる。レコードそのものの編集権限はデー タを投入した人または団体にあり，研究者の編集可 能なレコードへはデータがコピーされる。レコード 同士の“同じである” という表明やレコード内の属性 の検証を積み重ねて，研究者のレコードはオーソリ ティが高められていく。しかし，この方法では，新 しく登録したデータをどのように既存の識別子と関 連づければよいのか，同一研究者に対して複数の識 別子が存在してしまった時にどう対処すべきかにつ いては未解決である。これは重複解消のアプローチ とは別のアプローチであり，実際のシステムでどち らのアプローチをとるかはまだ決まっていない。

ビルダーの提案した方法は，技術作業部会におい てアルファシステムで考えたこととは異なる方法で あるが，実装のタイミングとしては，アルファシス テムの発展系として位置づけることができる。漸次 的にシステムを構築していくことで，システム全体 のオーソリティを高く保つようバランスをとること ができると展望している。

\section{8. その他関連する研究者の識別子}

研究者の識別子という観点からすると，ORCID以 外にも取り上げるべき活動は多く存在する。例えば， オランダのSURF財団の行ったDAI (Digital Author Identifier) ${ }^{13)}$ はオランダの研究者に研究者番号を割 り振っている。数物系のプレプリントサーバーArXiv もAuthor Identifiers ${ }^{14)}$ をオプトインの方式で導入 している。英国の情報システム合同委員会 (Joint Information Systems Committee: JISC) の助成を受け たNames Project ${ }^{15)}$ は，機関リポジトリの典拠を目指 して，研究者のIDを，英国図書館のジャーナル論文 と会議論文の書誌を収録するETOC (Electronic Table of Contents) のWebインターフェースであるZETOC のレコードをベースに研究者をクラスタリングして 自動で構築している。国立情報学研究所では，機関 リポジトリの典拠となることを目的の1つとした，研
究者リゾルバー16) を構築している。これは科学研究 費補助金データベースKAKEN ${ }^{17)}$ をベースにして研究 者のIDを付与している。

これらの研究者識別子に関するシステムも $\mathrm{RCID}$ のパートナーシステムとなることが可能であり，ID の登録とプロファイル交換の可能性がある。さらに， Web上での公開利用を前提としていることから，今 後はこれらの識別子同士がLinked Dataの技術をべー スに互いに同一人物を関係づけることによって連携 することも予想される。

より対象を広げてクリエーター一般に識別子を付 与していこうという動きもある。ISNI (International Standard Name Identifier) ${ }^{18)}$ は，現在ドラフト段階 のISO規格27729であり，メディアコンテンツ産業 に従事する団体に使われることを想定した規格であ る。ISNIのIDは16ケタの数字で，最後はチェックサム となっている。ISNI自体はURIとしてWeb上に公開す ることを明示するには至っていない。ISNIのIDは，商 用のIDシステムの上に展開されるオープンレイヤー として，IDシステム同士が必要最低限の情報を交 換してID間の対応を付けるブリッジ識別子 (Bridge Identifier）として機能する。交換する情報にはURIが 必須となっているので，複数の商用IDが紐づいたISNI のIDがURIとしてWeb上に展開される可能性は高い。

ORCIDとISNIは対象とする範囲で重複がある一方， 利用の組織や利用の方法が異なり，統合できるもの ではない。将来的にはID連携で両システムをつなげ ることが期待される。

\section{ORCIDの将来性}

ORCIDはまだ実際のサービスが開始されていない 未知数の試みであるが，筆者らの私見を含めてORCID の今後について考察する。

単純化すればORCIDは人間版のDOIである。DOIが あれば世界中のどこの出版社で出版された論文でも 確実に論文にたどり着けるのと同様に，ORCIDIDが 
あれば世界中の研究者に確実にたどり着けるという わけである。ただ，一度出版されれば変化しない論 文と異なり，研究者は活動中で変化するし，そもそ も意志ある存在であるので，単純ではない。常にアッ プデートが可能なような仕組みが必要であるし，多 様な活動を結びつけないといけない。より複雑な関 係を解決する仕組みが必要である。

ORCID IDは個人のIDである。単に個人にIDを付与 するというのであれば簡単である。しかし，2章で述 べたように研究活動を行う研究者というのは単純な 個人ではなく組織や社会の中に位置づけられる存在 である。このためORCID IDはこれらそれぞれの立場 の関係者の間で維持されないといけないという面倒 なIDである。

このため関係者が集合して中立的にORCIDを設立 して，この複雑な問題を解決しようと決めたという のは望ましいことであり，成功してもらいたいもの である。

では本当に普及するのであろうか？

名寄せやプライバシ一管理といった問題は技術的 に解決されなければならないし，また解決可能だと 考えている。むしろ，問題は社会的に受け入れられ るかという点である。

ORCIDIDの理想は全世界の研究者コミュニティー
のパスポートのようなものになることであろう。こ のパスポート取得には特に制約はない。ただこのパ スポートを持つことで研究コミュニティーの論文投 稿を含むさまざまなサービスにアクセス可能にな る。今や研究は直接間接にIT化されたサービスなしに は成り立たない。その意味では研究者に必須のもの となるであろう。

個人のIDには通常プライバシーと有用性のトレー ドオフがある。より有用なIDを作ると万一悪用され た時のプライバシー侵害の危険が高まる。しかし， 研究者のIDについては楽観的に考えている。そもそ も研究は個人的なものであると同時に公的なもので あるので，先のようなトレードオフによる障害は小 さい。むしろ近年のOpen Access運動にみるように研 究の公共性は今後より高まるであろう。公共性を重 視することは中立性をうたうORCIDを積極的に受け 入れる理由となる。この点ではORCIDは大きな可能 性がある。

今後の焦点は適切なビジネスモデル構築とサービ ス構築をいかにスピーディにできるかという点であ る。せっかくの機運がしぼまないうちに普及の軌道 にのせることができるかというところにかかってい る。

\section{本文の注}

注1）2010年11月11日にワーキンググループメンバーにメールで配布された報告資料による。ORCIDのメン バーとなることで，Wiki上で閲覧できる。

\section{参考文献}

1) "Research Stakeholders Announce Collaboration among Broad Cross-Section of Community to Resolve Name Ambiguity in Scholarly Research". ORCID. 2009-12-01. http://www.orcid.org/sites/default/files/ ORCID_Announcement.pdf, (accessed 2011-10-31).

2) "Organization Launched to Solve the Name Ambiguity Problem in Scholarly Research". ORCID. 2010-0907. http://www.orcid.org/sites/default/files/ORCIDInc-Press.pdf, (accessed 2011-10-31). 
3) "Mission Statement". ORCID. http://www.orcid.org/content/mission-statement, (accessed 2011-10-31).

4) "ORCID Principles". ORCID. http://www.orcid.org/principles, (accessed 2011-10-31).

5) "CCO 1.0 Universal (CCO 1.0) Public Domain Dedication". Creative Commons. http://creativecommons. org/publicdomain/zero/1.0/, (accessed 2011-01-14).

6) "Open Source Definition (Annotated), Version 1.9". Open Source Initiative. http://www.opensource.org/ osd.html, (accessed 2011-01-14).

7) VIVO. http://www.vivoweb.org/, (accessed 2011-10-31).

8) INSPIRE, beta. http://inspirebeta.net/, (accessed 2011-10-31).

9) RePEc. http://repec.org/, (accessed 2011-10-31).

10) "Author Resolver". RefWorks-COS. http://www.refworks-cos.com/authorresolver/, (accessed 2011-10-31).

11) "PubMed". National Center for Biotechnology Information. http://www.ncbi.nlm.nih.gov/pubmed, (accessed 2011-10-31).

12) Geoffrey Bilder. "Disambiguation without de-duplication: Modeling authority and trust in the ORCID system. Version 4". ORCID. http://www.orcid.org/sites/default/files/disambiguation-deduplication_wp_ v4.pdf, (accessed 2011-10-31).

13) "Digital Author Identifier (DAI)". SURF Foundation. http://www.surffoundation.nl/en/themas/ openonderzoek/infrastructuur/Pages/digitalauthoridentifierdai.aspx, (accessed 2011-10-31).

14) "Author Identifiers". ArXiv.org. http://arxiv.org/help/author_identifiers, (accessed 2011-10-31).

15) "Names Project". Mimas. http://names.mimas.ac.uk/, (accessed 2011-10-31).

16) “研究者リゾルバー”. 国立情報学研究所. http://rns.nii.ac.jp/, (accessed 2011-10-31).

17) “KAKEN—科学研究費補助金データベース”. 国立情報学研究所. http://kaken.nii.ac.jp/, (accessed 2011-1031).

18) ISNI - International Standard Name Identifier. http://www.isni.org/, (accessed 2011-10-31)..

\section{Author Abstract}

In this article, we introduce the activities of ORCID (Open Researcher and Contributor ID). ORCID aims to give unique identifiers to all researchers in the world. The identifiers are expected to make scientific communication more accurate and smoother. ORCID Inc, is created as Non-Profit Organization in USA by 14 organizations including major publishers, major universities and research institutions, and a funding agency. ORCID now collects almost 300 participating organizations from all over the world. ORCID ID will contribute to all stakeholders of scientific communication such as individual researchers, universities and research institutions, publishers, and funding agencies. ORCID will release the initial version of its service early in 2012, and then more functional version later in the year.

Key words

researcher identifier, researcher ID, name disambiguation, researcher profile, bibliography, ORCID, scholarly communication 